\title{
Amniotic membrane transplantation ineffective as additional therapy in patients with aggressive Mooren's ulcer
}

Maurice Schallenberg ${ }^{1,2^{*}}$, Henrike Westekemper ${ }^{1}$, Klaus-Peter Steuhl ${ }^{1}$ and Daniel Meller ${ }^{1}$

\begin{abstract}
Background: Mooren's ulcer is a severe ulcerative inflammation of the cornea. The exact pathogenesis remains unclear. Therefore many therapies of Mooren's ulcer are recommended in literature. To shed more light on the ongoing question of optimal treatment of severe progressive Mooren's ulcer, we here report on a retrospective case series of patients treated with systemic immunosuppressive therapy and additional amniotic membrane transplantation.

Methods: Medical records from seven patients (eleven eyes), 4 male and 3 female, with severe progressive Mooren's ulcer were analysed retrospectively. The mean follow up was 88.4 \pm 80.8 months (range 12-232 month). A HLA-typing was performed in all patients. A systemic immunosuppressive therapy was administered in all patients. The amniotic membrane was transplanted after the base of the ulcer was resected.

Results: Multiple amniotic membrane transplantations were necessary in six patients. The visual outcome of all patients was poor. No patient achieved a visual acuity better than 20/630 Snellen chart. Five patients were positive for HLA-DQ2 and four patients were positive for HLA-DR17(3).

Conclusions: The aggressive and highly inflammatory form of Mooren's ulcer is difficult to treat and the progression of the disease is hard to influence positively even under systemic immunosuppressive therapy. Therefore, the main intention of therapy is to achieve a stable epithelialized corneal surface without the risk of perforation. Amniotic membrane transplantation is not able to cure severe forms of Mooren's ulcer. However it supports the immunosuppressive therapy in acute situations as in critical corneal thinning.
\end{abstract}

Keywords: Cornea, Mooren's ulcer, Amniotic membrane, Autoimmune disease, Immunosuppressive therapy

\section{Background}

Mooren's ulcer is a severe ulcerative, uni- or bilateral inflammation of the cornea. Typically the inflammation starts in the peripheral cornea and the ulcer enlarges centrally and circumferentially - commonly associated with severe ocular pain. In late stages of the disease the destruction of the peripheral corneal stroma results in a conjunctivalized descemet membrane and in some cases corneal perforations occur. The progression and outcome of Mooren's ulcer differ between patients though the clinical appearance is similar. The exact pathogenesis

\footnotetext{
* Correspondence: maurice.schallenberg@uk-essen.de

'Department of Ophthalmology, University Hospital Essen, University of Duisburg-Essen, Hufelandstr 55, D-45147 Essen, Germany

${ }^{2}$ Augenklinik, HELIOS Klinikum Wuppertal, Heusnerstrasse 40, D-42283 Wuppertal, Germany
}

remains unclear even though the disease was first described by Bowman more than 150 years ago [1]. It is consensus that the Mooren's ulcer is an autoimmune disease that targets the cornea without other systemic disease association. Support for this idea came from Gottsch and colleagues who found antibodies against Calgranulin $\mathrm{C}$ in the serum of patients with Mooren's ulcer [2,3]. Calgranulin $C$ is uniquely expressed in cornea stromal tissue. Epidemiological studies from India identified a history of ocular trauma, previous cataract surgery, bacterial and helminth infection as risk factors to develop Mooren's ulcer [4].

Furthermore the disease occurs in populations living abroad and second generation migrants. Therefore the question of genetic predisposition arises. The highly

\section{Biomed Central}


polymorphic human lymphocyte antigens play an important role in immune response. An association to several autoimmune diseases such as rheumatoid arthritis, Graves'disease, and multiple sclerosis has been described [5]. Taylor and coworkers identified an association of HLADR17(3) and HLA-DQ2 to Mooren's ulceration [6].

Various therapies of Mooren's ulcer are recommended in literature. The excision of the conjunctiva around the ulceration combined with local or systemic steroids or coagulation of the base of the ulceration showed no long term benefit $[7,8]$. Authors from a large Chinese study of 550 patients who were treated with lamellar keratoplasty after topical resection of the ulceration, concluded that an adjuvant medication of topical ciclosporin A 1\% eye drops improves outcome [9]. They recommended topical ciclosporin A as therapeutic approach to modulate immune response. The stepladder of immunosuppressive agents used in Mooren's ulcer include prednisolone, methotrexate, azathioprine, cyclosporine, cyclophosphamide, and infliximab [9-12].

Recent studies suggest amniotic membrane transplantation (AMT) as a therapeutic approach in Mooren's ulcer. The idea of amniotic membrane transplantation as a therapeutic option in Mooren's ulcer came from the positive results shown by AMT of corneal ulceration due to other reasons. However, results reported in the literature with this procedure vary widely.

Recently, a retrospective study of 18 eyes reported a stabilization of the visual acuity and rapid healing of the epithelial defect after single AMT in most cases [13]. In contrast, results of AMT combined with conjunctival autografting or lamellar keratoplasty are less convincing $[14,15]$.

The growing evidence that Mooren's ulceration has an autoimmune genesis suggests an immunosuppressive therapy in Mooren's ulceration. In addition to systemic steroid therapy, ciclosporin A or cyclophosphamide is recommended in cases with severe progression or relapse [16,17].

To shed more light on the ongoing question of optimal treatment of severe progressive Mooren's ulcer, we here report a retrospective case series of patients treated with systemic immunosuppressive therapy and additional AMT.

\section{Methods}

Medical records from patients with severe progressive Mooren's ulcer were analysed retrospectively. They were treated between October 2002 and April 2012 at the University Eye Hospital Essen, Essen, Germany. The study was approved by the local ethics committee (Ethics Committee of the University Duisburg-Essen Nr. 13-5501-BO) and adhered to the tenets of the Declaration of Helsinki and local law.

Mooren's ulcer was diagnosed if an idiopathic painful peripheral corneal ulceration with typical clinical features and absence of scleral inflammation was observed. Infection was excluded by clinical and microbiological investigations. Other diagnoses causing peripheral corneal ulcerations (e.g. rheumatoid arthritis, Wegner's granulomatosis, other collagen vascular diseases, inflammatory bowel diseases, rosacea, Terrien's degeneration, or pellucid degeneration) were excluded by interdisciplinary clinical assessments and laboratory investigations. A HLA-typing was performed in all patients.

The systemic immunosuppressive therapy was administered in close collaboration with the clinic for hematology and clinic for nephrology of the University Hospital Essen, Essen, Germany to monitor the potentially serious side effects and the drug levels.

In cases of severe corneal thinning and highly inflammatory ulceration an AMT was performed. The amniotic membrane was obtained from the Cornea Bank Essen. The method of amniotic membrane preparation has been previous described by Kim and Tseng [18]. The surgical procedure was performed under peribulbar anaesthesia. The base of the ulcer was resected and an amniotic membrane graft (basement membrane oriented up) of similar size and shape was laid into the defect and sutured with 10-0 nylon sutures. In some cases the procedure was combined with a conjunctival resection and / or amniotic membrane patch which was sutured with $8-0$ vicryl sutures to the peribulbar conjunctiva.

The clinical findings and therapeutic response of AMT in addition to local and systemic immunosuppressive therapy were determined.

\section{Results}

Eleven eyes of seven patients, 4 male and 3 female, were enrolled in this retrospective interventional cases series. The mean age at the first presentation in our clinic was $62.8 \pm 15.7$ years (range $37-81$ years). The mean follow up was $88.4 \pm 80.8$ months (range $12-232$ month). Details of the patients' characteristics and clinical features are summarized in Table 1. One patient had a severe aggressive form of Mooren's ulcer on both eyes. In all other cases, one eye was affected by severe aggressive Mooren's ulcer with large deep ulcerations, the other eye was not affected in three cases, and only mild affected in the other three cases, respectively. Five patients were treated with intravenous cyclophosphamide as pulsetherapy and 2 patients with ciclosporin A orally as continuous therapy under drug monitoring. In addition, the patients were treated with ciclosporin A $0.05 \%$ eye drops three times daily as local immunosuppressive therapy. The supportive local therapy consisted of prednisolone acetate $1 \%$ three times daily, and sodium hyaluronate $0.1 \%$ and dexpanthenol, each instilled six times a day. Furthermore autologous serum $20 \%$ eye drops were applied six times a day. 
Table 1 Clinical features of patients with Mooren's ulceration

\begin{tabular}{lcccc}
\hline Case No. & Eye & Age & HLA DQ2 / DR17(3) & Depth of ulcer \\
\hline 1 & both & 81 & $+/+$ & $2 / 3$ \\
2 & OD & 68 & $+/-$ & $2 / 3$ \\
3 & OD & 68 & $-/-$ & $2 / 3$ \\
4 & OD & 37 & $-/+$ & $2 / 3$ \\
5 & both & 70 & $+/+$ & $2 / 3$ \\
6 & both & 45 & $+/+$ & Perforation \\
7 & both & 71 & $+/-$ & $2 / 3$ \\
\hline
\end{tabular}

Five patients were positive for HLA-DQ2 and four patients were positive for HLA-DR17(3).

In 6 patients multiple AMTs were necessary because of relapsing ulceration or persistent epithelial defects. A stabilization of the disease was achieved after one amniotic membrane grafting in only one patient. Representative images of the processes are presented in Figure 1.

The visual outcome of all patients was poor. No patient achieved a visual acuity better than 20/630 Snellen chart in the affected eye with severe aggressive Mooren's ulceration. Details of surgical procedure, follow up, immunosuppressive therapy and visual outcome are summarized in Table 2.

\section{Discussion}

Mooren's ulceration is a rare ulcerative inflammation of the cornea with quite a variable clinical progression and outcome for the patients. The diagnosis of Mooren's ulceration is difficult because other diseases causing a peripheral corneal ulceration have to be excluded in advance. Therefore, randomized prospective therapy studies are difficult to conduct and to date, even a recent Cochrane review in 2011 identified no randomized controlled trials for treatment of Mooren's ulcer [19].

Reviewing the literature, only case reports or retrospective cases series are published recommending therapeutic approaches based on theoretical considerations $[3,9,14,16,17]$. The definition of success seems to differ in the published literature. While some studies defined "healing" as success others used the "visual acuity" as primary end point [19].

The natural course of Mooren's ulceration is very different. In addition to the aggressive ulcerative forms, chronically inflammatory forms and spontaneous remissions are described. These facts make it difficult to evaluate and to compare the different recommended therapeutic approaches. Furthermore, the mean follow up after treatment is usually not longer than two years and in some reports no mean follow up is stated [9].

We report on seven Mooren's ulcer patients in a longterm follow up. The mean follow up in our interventional case series is 88.4 months \pm 80.8 . To our knowledge this

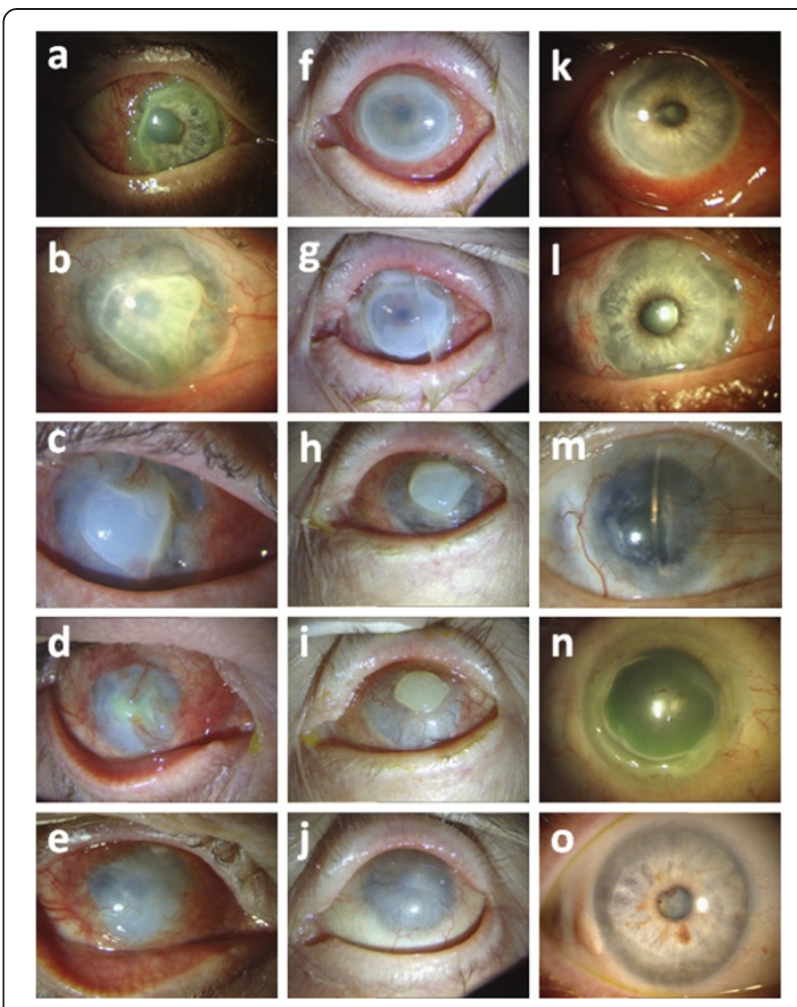

Figure 1 Representative images of the processes in some patients. a) - e) Right eye of case No. 5: a) corneal ulcer at the first visit; b) progression of the ulceration; c) + d) follow up after AMT; e) opacified epithelialized cornea at the last visit. $\mathbf{f}$ ) - j) Left eye of case No. 1: f) peripheral corneal ulcer at the first visit; $\mathbf{g}$ ) progression of the ulceration; h) + i) follow up after AMT; j) opacified epithelilized cornea at the last visit. $\mathbf{k}$ ) - $\mathbf{m}$ ) Right eye of case No.7: $\mathbf{k}$ ) corneal ulcer at the first visit; I) progression of the ulceration; $\mathbf{m}$ ) stabilized cloudy cornea with peripheral pannus after AMT and with immunosuppressive therapy. $\mathbf{n}$ ) - o) Right eye of case No. 2: $\mathbf{n}$ ) $360^{\circ}$ peripheral ulcer at the first visit; o) stabilized cornea with peripheral opacified scar under immunosuppressive therapy after AMT.

is the longest follow up ever published on patients with Mooren's ulcer.

Wood and Kaufman classified Mooren's ulcer into two main forms according to the age of onset, clinical characteristics, and the prognosis [20]. Type 1 is the benign form, generally monolateral with mild to moderate symptoms. This type was believed to affect mostly adults (over 35 years) and responds well to medical treatment and surgery. In contrast, type 2 is the malignant form that occurs with relatively more pain and generally responses poorly to any treatment. This type affects mostly younger patients (younger than 35 years) and a bilateralcondition in up to $75 \%$ of the cases that were reported in black patients. The classification of Watson divided the disease into three types based on the clinical appearance: (1) unilateral Mooren's ulcer, (2) bilateral aggressive Mooren's ulcer, and (3) bilateral indolent Mooren's ulcer [10]. With regard to bilaterality, perforation, age of onset, and recurrence rate 
Table 2 Follow up and therapy modalities of patients with Mooren's ulceration

\begin{tabular}{|c|c|c|c|c|c|c|c|}
\hline Case No. & $\begin{array}{l}\text { Follow up } \\
\text { time (month) }\end{array}$ & $\begin{array}{l}\text { Numbers of AM- transplantation/ } \\
\text { Surgical procedures }\end{array}$ & Immunosuppressive therapy & Topical immunosuppressivetherapy & $\begin{array}{l}\text { BCVA at } \\
\text { initial visit }\end{array}$ & $\begin{array}{l}\text { BCVA at last } \\
\text { follow up }\end{array}$ & $\begin{array}{l}\text { Epithelialisation (including } \\
\text { conjunctivalisation) }\end{array}$ \\
\hline \multirow[t]{2}{*}{1} & \multirow[t]{2}{*}{112} & $\mathrm{OD}: 2 x+\mathrm{KPL}$ & \multirow{2}{*}{$\begin{array}{l}\text { Cyclophosphamide (i.v:; ineffective) } \\
\text { FK-506 }\end{array}$} & \multirow[t]{2}{*}{ Cyclosporin A AT 0.5\% } & OD: $<20 / 4000$ & OD: $<20 / 4000$ & \multirow{2}{*}{$\begin{array}{l}2 \text { month after AMT and effective } \\
\text { immunosuppressive therapy }\end{array}$} \\
\hline & & OS: $3 x$ & & & OS: 20/4000 & OS: 20/4000 & \\
\hline 2 & 75 & OD: $1 \mathrm{x}$ & Cyclosporin A (orally) & Cyclosporin A AT 0.5\% & OD: 20/2000 & OD: 20/4000 & $\begin{array}{l}3 \text { month after AMT and effective } \\
\text { immunosuppressive therapy }\end{array}$ \\
\hline 3 & 14 & OD: $4 x$ & Cylclophosphamide (i.v.) & Cyclosporin A AT 0.5\% & OD: 20/80 & OD: 20/2000 & $\begin{array}{l}1 \text { month after AMT and effective } \\
\text { immunosuppressive therapy }\end{array}$ \\
\hline 4 & 12 & OD: $1 x$ & Cyclophosphamide (i.v.) & Cyclosporin A AT 0.5\% & OD: 20/32 & OD: 20/80 & $\begin{array}{l}1 \text { month after AMT and effective } \\
\text { immunosuppressive therapy }\end{array}$ \\
\hline \multirow[t]{2}{*}{5} & \multirow[t]{2}{*}{144} & \multirow[t]{2}{*}{ OD: $7 x+$ conjunctival resection } & \multirow{2}{*}{$\begin{array}{l}\text { Cyclophosphamide (i.v.; ineffective) } \\
\text { Cyclosporin A (orally; ineffective) } \\
\text { Tacrolimus }\end{array}$} & \multirow[t]{2}{*}{ Cyclosporin A AT 0.5\% } & OD: 20/32 & OD: $<20 / 4000$ & \multirow{2}{*}{$\begin{array}{l}3 \text { month after AMT and effective } \\
\text { immunosuppressive therapy }\end{array}$} \\
\hline & & & & & OS: $20 / 20$ & OS: 20/32 & \\
\hline \multirow[t]{2}{*}{6} & \multirow[t]{2}{*}{232} & \multirow[t]{2}{*}{ OD: $4 x+K P L$ enucleation } & \multirow[t]{2}{*}{ Cyclophosphamide (i.v.) } & \multirow[t]{2}{*}{ Cyclosporin A AT 0.5\% } & OD: $20 / 25$ & OD: - & \multirow{2}{*}{$\begin{array}{l}3 \text { month after KPL and effective } \\
\text { immunosuppressive therapy }\end{array}$} \\
\hline & & & & & OS: $20 / 25$ & OS: 20/40 & \\
\hline \multirow[t]{2}{*}{7} & \multirow[t]{2}{*}{30} & OD: $5 x+$ conjunctival resection & \multirow{2}{*}{$\begin{array}{l}\text { Cyclophosphamide (i.v.) } \\
\text { Azathioprine }\end{array}$} & \multirow[t]{2}{*}{ Cyclosporin A AT 0.5\% } & OD: 20/320 & OD: 20/800 & \multirow{2}{*}{$\begin{array}{l}3 \text { month after AMT and effective } \\
\text { immunosuppressive therapy }\end{array}$} \\
\hline & & OS: $3 x+$ conjunctival resection & & & OS: 20/32 & OS: $20 / 63$ & \\
\hline
\end{tabular}


our data are not in accordance to the classification of Wood and Kaufman. We report on cases of aggressive Mooren's ulcer in elderly patients (mean age 62.8 years \pm 15.6 ). These findings are supported by Lewallen and Courtright reviewing the literature on 287 cases of Mooren's ulcer who found a bilateral disease in $43 \%$ of older patients [21]. Chen and coworkers published a consecutive cases series of 550 patients obtained similar results, concluding that the bilateral disease is the malignant type of Mooren's ulcer [9]. Their findings are in contrast to the result of our case series, in which malignant aggressive processes were observed in unilateral Mooren's ulcer.

HLA-DQ2 and/or HLA-DR17(3) have been suggested to have a positive correlation to Mooren's ulcer. All of our patients tested positive for HLA-DQ2 or HLA-DR17 (3). We believe that the expression of HLA-DQ2 and/or HLA-DR17(3) may serve as prognostic factor in Mooren's ulceration, and may help to distinguish the severe aggressive form from the mild benign form of the disease. Further studies with larger patient cohorts are required to investigate this suggestion.

The growing evidence of Mooren's ulceration as an autoimmune disease has led to the recommendation of systemic immunosuppressive therapy in severe progressive, highly inflammative Mooren's ulcer [22]. Cyclophospamide and ciclosporin A are the most commonly used agents. Cyclophosphamide may be affective by suppressing B lymphocytes, which produce autoantibodies and promote an immune complex reaction [23]. In contrast, ciclosporin A may work by suppression of the $\mathrm{T}$ helper cell and stimulation of the $\mathrm{T}$ suppressor cell and cytotoxic $\mathrm{T}$ cells [24]. Both therapies are able to halt the progression in many patients with Mooren's ulcer $[16,24,25]$. Despite the use of the systemic immunosuppressive therapy in all patients, additional AMT was necessary because of a persistent peripheral corneal ulceration or a progressive corneal thinning. These findings are in accordance with the results of Mondino and Spelsberg who report on a progression of Mooren's ulceration under systemic immunosuppressive therapy in some cases $[25,26]$.

It is well known that AMT is able to improve the corneal epithelialisation and to support the remission of inflammation, neovascularisation, and corneal scars in several corneal diseases. The mechanism of action of AMT is to induce the apoptosis in inflammatory cells, the release of protease inhibitors, and suppression of fibroblast proliferation [27]. The most important growth factors that promote wound healing, which have been isolated from the $\mathrm{AM}$, are epidermal growth factor and keratocyte growth factor $[28,29]$. In addition, the AM produces basic fibroblast, hepatocyte and transforming growth factor (TGF). These growth factors together can stimulate epithelialisation, modulate proliferation, and induce differentiation of stromal fibroblasts [30].
The inhibition of TGF- $\beta$ signal transduction in corneal fibroblasts explains AM's anti-scarring effect [31]. In the initial phase after AMT, a significant reduction in inflammation is typical. The AM reduces expression of various growth factors and pro-inflammatory cytokines (e.g. interleukin 1a, IL -2, IL-8, interferon $\gamma$, tumor necrosis factor- $\beta$, basic fibroblast growth factor and platelet derived growth factor) [32]. Furthermore, the AM attracts and adheres to inflammatory cells infiltrating the ocular surface. In addition, the AM contains various forms of protease inhibitors [33]. This may explain some of its antiinflammatory properties. The reported immunomodulatory effect underlines the suggestion that AMT has a positive effect in healing Mooren's ulcer [34].

Recently, a retrospective study of 18 eyes reported a stabilization of the visual acuity and rapid healing of the epithelial defect after single AMT in most cases [13]. Ngan and Chau reported in a rapid epithelialisation and a good visual outcome especially in patients with limited corneal ulceration. In patients with $360^{\circ}$ ulceration, as was seen in most of our cases, the time of epithelialisation was up to one month and the visual outcome was poor. Another limitation of this study is the short follow up time (1.5 to 20 month). In addition, the authors did not ensure their diagnosis by assessing HLA-DQ2 and HLA-DR17(3).

The reported results of AMT combined with conjunctival autografting or lamellar keratoplasty are less convincing $[14,15]$. The authors claimed a positive effect of AMT in their studies but there are several limitations. Zhou and colleagues combined AMT with lamellar keratoplasty for patients with recurrent Mooren's ulcer. They found a delayed recurrence in their cases but they did not differentiate the effect of lamellar keratoplasty from the AMT. In addition, they reported a short follow up time (12 to 29 month). Chen et al. reported on one case of initial successfully sealed corneoscleral perforation, a relapse after 2 months with infiltration along the conjuncival graft. After removing the conjuntival graft and a second AMT the leason was stable over 1 year. One case has a very limited value in a disease in which the natural course is very different and spontaneous remissions are described.

In contrast to those studies we report on cases of aggressive Mooren's ulcer with large coneal ulcers in which AMT was not able to stabilize the processes of the disease. In most of our cases (6 of 7) we could identify HLA-DQ2 or HLA-DR17(3) which seems to be highly associated to Mooren's ulcer and may be a prognostic factor. These findings emphasize our diagnosis of Mooren's ulcer.

The anti-inflammatory potential of amniotic membrane may be useful in Mooren's ulcer in some cases to support the systemic immunosuppressive therapy. The fact that 5 patients needed multiple AMT showed clearly that amniotic membrane is not able to stop the immunological process or even cure Mooren's ulcer in aggressive processes. 


\section{Conclusion}

In conclusion, the aggressive highly inflammatory form of Mooren's ulcer is difficult to treat and so far there is no optimal therapy for Mooren's ulcer. The progression of the disease is hard to influence positively even under systemic immunosuppressive therapy and intensive local medication. Therefore, the main intention of therapy is to achieve a stable epithelialized corneal surface without the risk of perforation than to maintain the visual acuity. AMT is not able to cure severe forms of Mooren's ulcer because the disease is based on an immunological process. However it supports the immunosuppressive therapy in acute situations like critical corneal thinning or persistent epithelial defects.

\section{Abbreviations}

AM: Amniotic membrane; AMT: Amniotic membrane transplantation; HLA: Human leukocyte antigene.

\section{Competing interests}

The authors declare that they have no competing interests.

\section{Authors' contribution}

MS participated in conception and design, data collection, data analysis and drafting the manuscript. HW participated in data collection, data analysis and critically revising the manuscript. K-PS performed the operations and participated in data analysis and critically revising the manuscript. DM performed the operations and participated in conception and design, data collection, data analysis and critically revising the manuscript. All authors read and approved the final manuscript.

Received: 25 July 2013 Accepted: 9 December 2013

Published: 17 December 2013

\section{References}

1. Bowman W: The parts concerned in the operations of the eye (1849), cited by Nettleship, E: chronic serpiginous ulcer of the Cornea (Mooren's Ulcer). Trans Ophthalmol Soc U K 1902, 22:103-104. Case 12, p 112.

2. Gottsch JD, Liu SH, Minkovitz JB, Goodman DF, Srinivasan M, Stark WJ: Autoimmunity to a cornea-associated stromal antigen in patients with Mooren's ulcer. Invest Ophthalmol Vis Sci 1995, 36(8):1541-1547.

3. Zhao JC, Jin XY: Immunological analysis and treatment of Mooren's ulcer with cyclosporin a applied topically. Cornea 1993, 12(6):481-488.

4. Zegans ME, Srinivasan M, McHugh T, Whitcher JP, Margolis TP, Lietman T, Jennette JC, Cunningham ET Jr: Mooren ulcer in South India: serology and clinical risk factors. Am J Ophthalmol 1999, 128(2):205-210.

5. Heard R: HLA and autoimmune disease. In HLA and disease. Edited by Lechler R. London: Academic press; 1994:123-151.

6. Taylor CJ, Smith SI, Morgan CH, Stephenson SF, Key T, Srinivasan M, Cunningham E Jr, Watson PG: HLA and Mooren's ulceration. Br J Ophthalmol 2000, 84(1):72-75.

7. Faye M, Lam A, Borzeix A: Treatment of Mooren's ulcer by the combination of periectomy and corticotherapy. Apropos of 6 cases. J Fr Ophtalmol 1991, 14(11-12):629-632.

8. Pau H: The therapy of Mooren's rodent ulcer. Klin Monbl Augenheilkd 1978, 173(1):62-68.

9. Chen J, Xie H, Wang Z, Yang B, Liu Z, Chen L, Gong X, Lin Y: Mooren's ulcer in China: a study of clinical characteristics and treatment. $\mathrm{Br} J$ Ophthalmol 2000, 84(11):1244-1249.

10. Watson PG: Management of Mooren's ulceration. Eye (Lond) 1997, 11(Pt 3):349-356.

11. Ashar JN, Mathur A, Sangwan VS: Immunosuppression for Mooren's ulcer: evaluation of the stepladder approach-topical, oral and intravenous immunosuppressive agents. $\mathrm{Br} J$ Ophthalmol 2013. Epub ahead of print

12. Fontana L, Parente $G$, Neri $P$, Reta M, Tassinari G: Favourable response to infliximab in a case of bilateral refractory Mooren's ulcer. Clin Experiment Ophthalmol 2007, 35(9):871-873.
13. Ngan ND, Chau HT: Amniotic membrane transplantation for Mooren's ulcer. Clin Experiment Ophthalmol 2011, 39(5):386-392.

14. Chen KH, Hsu WM, Liang CK: Relapsing Mooren's ulcer after amniotic membrane transplantation combined with conjunctival autografting. Ophthalmology 2004, 111(4):792-795.

15. Zhou S, Chen J, Fung B, Chen L: Fresh amniotic membrane transplantation combined lamellar keratoplasty for patients with recurrent Mooren's ulcer. Yan Ke Xue Bao 2003, 19(1):1-5.

16. Foster CS: Systemic immunosuppressive therapy for progressive bilateral Mooren's ulcer. Ophthalmology 1985, 92(10):1436-1439.

17. Tiev KP, Borderie VM, Briant M, Ziani M, Morvant C, Baret M, El Khattabi A, Généreau T, Laroche L, Cabane J: Severe Moorens ulcer: efficacy of monthly cyclophosphamide intravenous pulse treatment. Rev Med Interne 2003, 24(2):118-122.

18. Kim JC, Tseng SC: Transplantation of preserved human amniotic membrane for surface reconstruction in severely damaged rabbit corneas. Cornea 1995, 14(5):473-484.

19. Alhassan MB, Rabiu M, Agbabiaka IO: Interventions for Mooren's ulcer. Cochrane Database Syst Rev 2011, 15(6):CD006131.

20. Wood TO, Kaufman HE: Mooren's ulcer. Am J Ophthalmol 1971, 71(1 Pt 2):417-422.

21. Lewallen $S$, Courtright P: Problems with current concepts of the epidemiology of Mooren's corneal ulcer. Ann Ophthalmol 1990, 22(2):52-55.

22. Sangwan VS, Zafirakis P, Foster CS: Mooren's ulcer: current concepts in management. Indian J Ophthalmol 1997, 45(1):7-17.

23. Lopez JS, Price FW Jr, Whitcup SM, Li Q, de Smet M, Chan CC: Immunohistochemistry of Terrien's and Mooren's corneal degeneration. Arch Ophthalmol 1991, 109(7):988-992.

24. Wakefield D, Robinson LP: Cyclosporin therapy in Mooren's ulcer. Br J Ophthalmol 1987, 71(6):415-417.

25. Brown SI, Mondino BJ: Therapy of Mooren's ulcer. Am J Ophthalmol 1984, 98(1):1-6.

26. Spelsberg H, Sundmacher R: Amniotic membrane transplantation and high-dose systemic cyclosporin a (Sandimmun optoral) for Mooren's ulcer. Klin Monbl Augenheilkd 2007, 224(2):135-139.

27. Tseng SCG, Tsubota K: In Amniotic membrane transplantation for ocular surface reconstruction. Edited by Holland EJ, Mannis MJ. New York: Springer; 2002:226-231.

28. Koizumi NJ, Inatomi TJ, Sotozono CJ, Fullwood NJ, Quantock AJ, Kinoshita S: Growth factor mRNA and protein in preserved human amniotic membrane. Curr Eye Res 2000, 20(3):173-177.

29. Tseng SC, Espana EM, Kawakita T, Di Pascuale MA, Li W, He H, Liu TS, Cho TH, Gao YY, Yeh LK, Liu CY: How does amniotic membrane work? Ocul Surf 2004, 2(3):177-187.

30. Sato $H$, Shimazaki J, Shinozaki N: Role of growth factors for ocular surface reconstruction after amniotic membrane transplantation. Invest Ophthalmol Vis Sci 1998, 39:S428.

31. Lee SB, Li DQ, Tan DT, Meller DC, Tseng SC: Suppression of TGFbeta signaling in both normal conjunctival fibroblasts and pterygial body fibroblasts by amniotic membrane. Curr Eye Res 2000, 20(4):325-334.

32. Solomon A, Rosenblatt M, Monroy D, Ji Z, Pflugfelder SC, Tseng SC: Suppression of interleukin 1alpha and interleukin 1beta in human limbal epithelial cells cultured on the amniotic membrane stromal matrix. Br J Ophthalmol 2001, 85(4):444-449.

33. Shimmura S, Shimazaki J, Ohashi Y, Tsubota K: Antiinflammatory effects of amniotic membrane transplantation in ocular surface disorders. Cornea 2001, 20(4):408-413.

34. Ueta M, Kweon MN, Sano Y, Sotozono C, Yamada J, Koizumi N, Kiyono H, Kinoshita S: Immunosuppressive properties of human amniotic membrane for mixed lymphocyte reaction. Clin Exp Immunol 2002, 129(3):464-470.

doi:10.1186/1471-2415-13-81

Cite this article as: Schallenberg et al:: Amniotic membrane transplantation ineffective as additional therapy in patients with aggressive Mooren's ulcer. BMC Ophthalmology 2013 13:81. 